\title{
Growth Response and Gene Expression in Antioxidant-related Enzymes in Two Bermudagrass Genotypes Differing in Salt Tolerance
}

\author{
Longxing Hu${ }^{1}$, Zehui Huang ${ }^{1}$, Shuqian Liu, and Jinmin $\mathbf{F u}^{2}$ \\ Key Laboratory of Plant Germplasm Enhancement and Specialty Agriculture, Wuhan Botanical \\ Garden, The Chinese Academy of Science, Wuhan City, Hubei, 430074, P.R. China
}

\begin{abstract}
Plant adaptation to salt stress may be associated with morphological, physiological, and gene expression alterations. The objective of this study was to investigate the effect of salt stress on morphological and antioxidant enzyme changes and its gene expressions in bermudagrass (Cynodon dactylon). Salt-tolerant ' $C 43$ ' and salt-sensitive 'C198', previously determined in our preliminary study, were subjected to four salinity levels: $0 \mathrm{~mm}$ (control), $100 \mathrm{~mm}$ (low), $200 \mathrm{~mm}$ (moderate), and $400 \mathrm{~mm}$ (high) $\mathrm{NaCl}$ for 21 days. Salt stress decreased turf quality and canopy height, especially in 'C198'. Salt stress increased root length, root number, root fresh weight, and root/shoot length ratio, to a greater extent in salt-tolerant genotype. Salt stress increased $\mathrm{Na}^{+}$and decreased $\mathrm{K}^{+}$content, which resulted in a higher $\mathrm{Na}^{+} / \mathrm{K}^{+}$ratio in bermudagrass, to a great extent in shoot and root of ' $\mathrm{C} 198$ '. Moderate (200 mM) and high (400 $\mathrm{mm}$ ) salt concentration increased malondialdehyde and hydrogen peroxide content in old leaves of ' $\mathrm{C} 198$ '. ' $\mathrm{C} 43$ ' exhibited a greater activity of superoxide dismutase (SOD), catalase (CAT), ascorbate peroxidase (APX), and dehydro-ascorbate reductase (DHAR) than 'C198' in old leaves subjected to 200 and $400 \mathrm{~mm} \mathrm{NaCl}$. Antioxidant gene expressions were upregulated in new leaves and downregulated in old leaves with increasing salinity levels for both genotypes. Salt-tolerant genotypes exhibited a relatively greater antioxidant gene expression than salt-sensitive ones when exposed to the same level of salt stress. These results suggested that SOD, CAT, APX, and DHAR might be involved in scavenging salt stress-induced reactive oxygen species in bermudagrass at the level of gene expression. Salt tolerance might be attributed to the development and maintenance of a more extensive root system under saline conditions and induced antioxidant gene expressions, leading to more efficient enzyme stimulation and protection in bermudagrass.
\end{abstract}

Salt stress is one of the major abiotic factors that affects plant growth. Shoot and root growth reduction is a common response to salt stress because plant growth is one of the most important agricultural indicators of salt stress tolerance (Hulusi et al., 2007). Plant adaptation to salt is a complex phenomenon that may involve growth changes as well as physiological and biochemical processes (Hare et al., 1997). Salinity injury to plants was attributed to lower osmotic potential $\left(\psi_{\mathrm{S}}\right)$ and ion effect (Munns, 2002). Lower $\psi_{\mathrm{S}}$ reduces the ability of the plant to absorb water and induces physiological drought (Munns and Tester, 2008). The excessive uptake of $\mathrm{Na}^{+}$or $\mathrm{Cl}^{-}$can limit the uptake of other nutritional ions such as $\mathrm{K}^{+}, \mathrm{Ca}^{2+}$, and $\mathrm{Mg}^{2+}$; cause adverse effects on ion homeostasis, which lead to premature leaf aging; less cell division and elongation; and reduces leaf and root growth (Munns, 2002; Zhu, 2001).

In addition, salinity also results in oxidative stress in plants as a result of the overproduction of reactive oxygen species (ROS) such as the super oxide radical $\left(\mathrm{O}_{2}^{-}\right)$, hydrogen peroxide $\left(\mathrm{H}_{2} \mathrm{O}_{2}\right)$, and hydroxyl radical $(\bullet \mathrm{OH})$. The oxygen species are detrimental to membrane lipids, proteins, and nucleic acids (Murillo-Amador et al., 2006). To minimize the adverse effects of ROS, plants have evolved an efficient enzymatic and nonenzymatic antioxidant system (Abdul-Jaleel et al., 2006). In the

Received for publication 6 Apr. 2012. Accepted for publication 8 May 2012. This work was financially supported by the Young Scientists Fund of the National Natural Science Foundation of China (Grant No. 31101563) and the Main Direction Program of Knowledge Innovation of Chinese Academy of Sciences (Grant No. 092A281X02).

${ }^{1}$ These authors contributed equally to this work

${ }^{2}$ Corresponding author. E-mail: jinminfu@gmail.com. enzymatic system, superoxide dismutase catalyzes the dismutation of $\mathrm{O}_{2}^{-}$into $\mathrm{H}_{2} \mathrm{O}_{2}$ and $\mathrm{O}_{2}$ (Sigaud-Kutner et al., 2002). Catalase, AOX, and DHAR decompose $\mathrm{H}_{2} \mathrm{O}_{2}$ to $\mathrm{H}_{2} \mathrm{O}$ at different cellular locations (Edreva, 2005). The mechanisms regulating the activity and gene expression of different antioxidant enzymes are complex because the genes respond to environmental stress differentially (Sen Gupta et al., 1993). A higher level of these antioxidant enzyme activities is considered as one of the salt tolerance mechanisms in most plants (Ashraf, 2009). Previous studies demonstrated that salt-tolerant genotypes generally have a higher constitutive or an enhanced antioxidant enzyme activity under salt stress than the sensitive ones (Amor et al., 2006; Hu et al., 2012a; Mhadhbi et al., 2011). However, the response of plant antioxidant systems to salt varied for different plant species and the tissues (Mittova et al., 2003).

Bermudagrass is one of the most widely used warm-season turfgrass species in temperate and tropical regions, which has shown good tolerance to salinity and can survive in saline soil (Mancino and Pepper, 1994). To our knowledge, most previous studies examined in bermudagrass under salinity conditions were at either morphological or physiological levels (Adavi et al., 2006; Akram et al., 2006; Alshammary et al., 2008; Hameed et al., 2010; Lu et al., 2007; Marcum et al., 2005; Marcum and Pessarakli, 2006; Shahba, 2010). Little research has investigated antioxidant response to salinity at the level of gene expression and enzyme activity. The objective of this study was to investigate the effects of different salinity levels on the growth as well as the antioxidant defense system at the enzyme and gene expression levels in two genotypes of bermudagrass differing in salt tolerance. 


\section{Materials and Methods}

Plant materials and growth CONDitions. Uniform stolons (5 cm long) of bermudagrass, 'C43' (salt-tolerant) and 'C198' (salt-sensitive), previously determined in our preliminary study, were planted in solid growth substances (2 peat soil:1 sand, v/v). After $14 \mathrm{~d}$ of establishment, an equal amount of plants was vegetatively grown in plastic pots $(7 \mathrm{~cm}$ diameter and $9 \mathrm{~cm}$ tall) filled with coarse silica sand as the plant anchor medium. Pots were suspended over tubs containing $46 \mathrm{~L}$ of constantly aerated half-strength Hoagland's solution (Hoagland and Arnon, 1950). The tubs were refilled every other day and renewed weekly. Pot bottoms consisted of a coarse nylon screen allowing roots to freely grow into the solutions. Plants were grown in an environmentally controlled walk-in growth chamber with the temperature regime of $30 / 25{ }^{\circ} \mathrm{C}$ (day/night) and photosynthetically active radiation levels of $1100 \mu \mathrm{mol} \cdot \mathrm{m}^{-2} \cdot \mathrm{s}^{-1}$ at canopy height for $14 \mathrm{~h}$. Plants were allowed to grow in this nutrient solution for $35 \mathrm{~d}$. During this period, the plant shoots were hand-clipped weekly at $4-\mathrm{cm}$ height, and roots were clipped back to the bottoms of the pots at the beginning of the salt treatment to allow the plants to reach full maturity and develop uniform and equal size roots and shoots.

Treatments and experimental Design. Two bermudagrass genotypes were subjected to four salinity levels: $0 \mathrm{~mm}$ (control), $100 \mathrm{~mm}$ (low), $200 \mathrm{~mm}$ (moderate), and $400 \mathrm{~mm}$ (high) $\mathrm{NaCl}$. Salinity was increased in three tanks (each tank containing both genotypes) by daily increments of $50 \mathrm{~mm} \mathrm{NaCl}$ until a final salinity level of 100, 200, and $400 \mathrm{~mm}$ was reached. One other tank was maintained as a control Hoagland's solution without the addition of $\mathrm{NaCl}$.

After the final salinity level (400 mM) was reached ( $8 \mathrm{~d}$ after the initiation of the salt treatment), the shoots and roots were clipped. Grasses were exposed to final salinity concentrations for 3 weeks. During the period of salt exposure, the culture solutions were aerated with an air pump and changed weekly to maintain the desired nutrient levels. At the end of the experiment, the visual turf quality, canopy height, root length, and root numbers were determined. Plants were separated into roots, old leaves (fully expanded leaf before start salt treatment), and new leaves (the youngest fully expanded leaf after salt treatment) and then immediately frozen in liquid nitrogen and stored at $-80^{\circ} \mathrm{C}$ for further analysis. The salt treatments and grass genotypes were arranged in a randomized complete block design with six replicates.

Measurements. Turf quality (TQ) was visually assessed based on turfgrass color (extent of chlorosis and leaf senescence), plant density, and degree of leaf wilting using a scale of 1 to 9 , where $1=$ brown, senesced, and dehydrated turf; $6=$ minimum acceptable quality; and 9 = fully turgid, green and healthy turf.

Canopy height was determined by the difference in turf canopy height before and after salt treatment according to the method of Hu et al. (2012b) and Huang and Liu (2009). Canopy height was measured in four positions in each pot using a ruler and was averaged. Root number (RN) and length (RL) were determined only for roots elongating from the nylon screen at the pot bottom. Roots were counted and measured for their length in each pot at Day 21. At the end of the experiment, plant roots were harvested, rinsed with deionized water, dried by blotting the root with a paper towel, and were immediately weighed for root fresh weight. Then, the root/shoot length ratio (average root length/canopy height) of the seedlings was determined.

For crude enzyme extraction, plant tissues were finely ground into powder in liquid nitrogen and then homogenized in ice-cold sodium phosphate buffer ( $50 \mathrm{~mm}, \mathrm{pH} 7.0)$. For assay of APX and DHAR, $2 \mathrm{~mm}$ ascorbic acid, $0.5 \mathrm{~mm}$ ethylene diaminetetraacetic acid (EDTA), and 2\% polyvinylpyrrolidin were added to the enzyme extraction buffer. The homogenate was centrifuged at $13,000 g_{\mathrm{n}}$ for $15 \mathrm{~min}$ at $4{ }^{\circ} \mathrm{C}$. The supernatants were used as the crude extract for SOD, CAT, APX, and DHAR assay as we described before (Hu et al., 2012a, 2012b). Soluble proteins were quantified by the method of Bradford (1976) with bovine serum albumin as the standard. All spectrophotometric analyses were conducted using a spectrophotometer [ultraviolet2600; UNICO (Shanghai) Instruments Co., Shanghai, P.R. China).

For determination of SOD activity, the $3-\mathrm{mL}$ reaction solution contained $50 \mathrm{~mm}$ sodium phosphate buffer $(\mathrm{pH} 7.8)$, $195 \mathrm{~mm}$ methionine, $3 \mu \mathrm{M}$ EDTA, $1.125 \mathrm{~mm}$ nitro blue tetrazolium (NBT), $60 \mu \mathrm{M}$ riboflavin, and $100 \mu \mathrm{L}$ of enzyme extract with non-enzyme solution as a control. The reaction mixtures were illuminated under $200 \mu \mathrm{mol} \cdot \mathrm{m}^{-2} \cdot \mathrm{s}^{-1}$ irradiance for $20 \mathrm{~min}$. Absorbance changes at $560 \mathrm{~nm}$ were monitored for 3 min by a spectrophotometer. One unit of SOD activity was defined as the amount of enzyme required to inhibit the NBT reduction by $50 \%$.

For the measurement of CAT activity, the $3-\mathrm{mL}$ reaction mixture contained $50 \mathrm{~mm}$ sodium phosphate buffer $(\mathrm{pH} 7.0)$, $45 \mathrm{mM} \mathrm{H}_{2} \mathrm{O}_{2}$. The reaction was initiated by adding the $100 \mu \mathrm{L}$ of enzyme extract, and the decrease in absorbance at $240 \mathrm{~nm}$ was recorded every $1 \mathrm{~min}$ for $3 \mathrm{~min}$. One unit of CAT activity was defined as the absorbance changes of 0.01 units $/ \mathrm{min}$.

APX activity was determined by monitoring the rate of ascorbate oxidation at $290 \mathrm{~nm}$. Briefly, the 3-mL reaction mixture contained $50 \mathrm{~mm}$ sodium-acetic buffer ( $\mathrm{pH} 5.8$ ), $5 \mathrm{~mm} \mathrm{H}_{2} \mathrm{O}_{2}$, $10 \mathrm{~mm}$ ascorbate, $3 \mu \mathrm{M}$ EDTA, and $100 \mu \mathrm{L}$ of enzyme extract. The decrease in absorbance was recorded at $290 \mathrm{~nm}$ at an interval of $10 \mathrm{~s}$ up to $90 \mathrm{~s}$. One unit APX was defined as the absorbance change of 0.01 units per minute.

DHAR activity was determined by measuring increase in absorbance at $265 \mathrm{~nm}$ as a result of the reduction of dehydroascorbate according to the method of Nakano and Asada (1981) with slight modifications. Briefly, the reaction mixture consisted of $0.5 \mathrm{~mL}$ of $50 \mathrm{~mm}$ sodium phosphate buffer ( $\mathrm{pH} 7.0), 0.1 \mathrm{~mL}$ of $1 \mathrm{~mm}$ EDTA, $0.1 \mathrm{~mL}$ of $5 \mathrm{~mm}$ reduced glutathione (GSH), and $0.1 \mathrm{~mL}$ of enzyme extract. The reaction was initiated by the addition of $0.2 \mathrm{~mL}$ of $0.06 \mathrm{~mm}$ dehydroascorbate. The increase in absorbance at $265 \mathrm{~nm}$ was monitored for $5 \mathrm{~min}$. DHAR activity was calculated as nanomoles ascorbic acid (ASA) per minute per milligram protein.

Malondialdehyde (MDA) content was determined by the thiobarbituric acid (TBA) reaction using the method of Heath and Packer (1968) with slight modifications as we described before (Hu et al., 2012a). Briefly, $1 \mathrm{~mL}$ of enzyme extraction was mixed with $1 \mathrm{~mL}$ of reaction solution containing $20 \%(\mathrm{v} / \mathrm{v})$ trichloroacetic acid and $0.5 \%(\mathrm{v} / \mathrm{v})$ TBA. The mixture was heated in a water bath at $95{ }^{\circ} \mathrm{C}$ for $30 \mathrm{~min}$ and then cooled to room temperature and centrifuged at $10,000 g_{\mathrm{n}}$ for $10 \mathrm{~min}$. Absorbance of the supernatant was measured at 532 and $600 \mathrm{~nm}$. The content of MDA was calculated by subtracting the nonspecific absorption at $600 \mathrm{~nm}$ from the absorption at $532 \mathrm{~nm}$ and calibrated by using the extinction coefficient of $155 \mathrm{~mm} \mathrm{~m}^{-1} \cdot \mathrm{cm}^{-1}$ (Heath and Packer, 1968). 
The content of $\mathrm{H}_{2} \mathrm{O}_{2}$ was determined using the method described by Jena and Choudhuri (1981) with minor modifications. Briefly, $1 \mathrm{~mL}$ of supernatant was mixed thoroughly with $1 \mathrm{~mL}$ of $0.1 \%$ titanium sulphate in $20 \% \mathrm{H}_{2} \mathrm{SO}_{4}(\mathrm{v} / \mathrm{v})$, and the mixture was then centrifuged at $6000 \mathrm{~g}_{\mathrm{n}}$ for $15 \mathrm{~min}$ at room temperature. The absorbance of the yellow color of the supernatant was measured at $410 \mathrm{~nm}$. The $\mathrm{H}_{2} \mathrm{O}_{2}$ level was calculated from the standard curve generated with known concentrations of $\mathrm{H}_{2} \mathrm{O}_{2}$ and calibrated with the extinction coefficient of $0.28 \mu \mathrm{mol}^{-1} \cdot \mathrm{cm}^{-1}$.

For $\mathrm{Na}^{+}$and $\mathrm{K}^{+}$determination, the plant materials were dried in an oven at $80^{\circ} \mathrm{C}$, finely ground, and passed through a 2-mm mesh sieve. Samples were digested in $5 \mathrm{~mL}$ of $98 \% \mathrm{H}_{2} \mathrm{SO}_{4}$ and $3 \mathrm{~mL}$ of $30 \% \mathrm{H}_{2} \mathrm{O}_{2}$ for $5 \mathrm{~h}$. The $\mathrm{Na}^{+}$and $\mathrm{K}^{+}$content of the mineral extract was determined using a flame photometer.

Total RNA was extracted from fresh tissues by using Trizolreagent (Invitrogen, Carlsbad, CA) according to the manufacturer's instructions. After extraction, the RNA pellet was dissolved in $100 \mu \mathrm{L}$ of RNase-free water. RNase-free DNase I was added to the total RNA to remove DNA contamination. The total RNA concentration was then determined by absorbance at $260 \mathrm{~nm}$ and RNA quality was evaluated on a $0.8 \%$ agarose gel.

For reverse transcription-polymerase chain reaction, cDNA was prepared from $2 \mu \mathrm{g}$ of total RNA with oligo(dT) ${ }_{12-18}$ primer using a cDNA synthesis kit (Fermentas, Burlington, Ontario, Canada) according to the user manual. The resulting cDNA was stored in aliquots at $-20{ }^{\circ} \mathrm{C}$ until further use. Genespecific primers (Table 1) were synthesized based on a previously identified expressed sequence tag sequence in bermudagrass. Actin gene was used to confirm equal template loading. General polymerase chain reaction (PCR) was conducted with the following program: inactivated the reverse transcriptase at $94{ }^{\circ} \mathrm{C}$ for $3 \mathrm{~min}$ and then followed with $94{ }^{\circ} \mathrm{C}$ for $30 \mathrm{~s}, 50$ to $55^{\circ} \mathrm{C}$ for $30 \mathrm{~s}$, and $72{ }^{\circ} \mathrm{C}$ for $30 \mathrm{~s}$ with 30 to 35 cycles. The PCR products were evaluated on a $1.3 \%$ agarose gel in $1 \times$ Trisacetate-ethylenediaminetetraacetic acid and stained with ethidium bromide. The band intensity was quantified by using imaging software (Tanon 2500; Tanon Science and Technology Co., Shanghai, P.R. China).

STAtistical AnAlysis. All data were subjected to analysis of variance by using the general linear model procedure of SAS (Version 9.0 for Windows; SAS Institute, Cary, NC) to determine the treatment effects and genotypic variations in growth and physiological response. Treatment means and genotype differences were separated using the least significant

Table 1. The gene-specific primer sequence for polymerase chain reaction used for detecting gene expression in leaves of bermudagrass.

\begin{tabular}{llll}
\hline Accession & Gene name & & \multicolumn{2}{c}{ Primer sequence $\left(5^{\prime}-3^{\prime}\right)$} \\
\hline BG322311 & APX & F & TCCGTGAAGTAAGAGTTGTC \\
& & R & CAGATGGGCTTGAGTGAT \\
DN987297 & CAT & F & GGCTGGTTCCTTTCGTTT \\
& & R & TCGGTTTCATTTGGCTGT \\
JK340747.1 & DHAR & F & GTTGGTGAGGCTTTCTGG \\
& & R & GGTGATGGCAAGTGGATT \\
JK340708.1 & Cu/Zn SOD & F & TCTTCCACCAGCATTCC \\
& & R & AGGCGTGGCTGAGACAAC \\
& \multirow{2}{*}{ Actin } & F & AGGCATCCAACCAGCAGAGA \\
& & R & ACTCAGCACATTCCAGCAGAT
\end{tabular}

$\overline{\mathrm{APX}}=$ ascorbate peroxidase; CAT $=$ catalase; DHAR $=$ dehydroascorbate reductase; $\mathrm{Cu} / \mathrm{Zn} \mathrm{SOD}=$ copper/zinc superoxide dismutase. difference test at $P<0.05$. The allometric relationship between shoot and root was examined by regressing shoot height over root length by fitting quadratic polynomials using SigmaPlot 10.0 (Systat Software, Richmond, CA).

\section{Results}

Growth RESPONSE TO SALT STRESS. Visual TQ significantly decreased with increasing salinity levels in both genotypes, to a greater extent in salt-sensitive ' $\mathrm{C} 198$ ' vs. the respective control level (Fig. 1A). There was no difference in TQ between two genotypes subjected to low (100 mM) salt stress. The 200- and 400 mM-treated plants had a greater level of TQ than 'C198'. Relative canopy height (as a percent of control) decreased with increasing salinity levels in both genotypes (Fig. 1B). However, there was no difference in relative canopy height between two genotypes regardless of salinity levels.

Root growth (i.e., relative root length and number to the control) of ' $\mathrm{C} 43$ ' and ' $\mathrm{C} 198$ ' responded differentially to increasing salinity levels (Fig. 2). The $\mathrm{NaCl}$-treated ' $\mathrm{C} 43$ ' had a relative longer $\mathrm{RL}$ and more $\mathrm{RN}$ than the control plants during the whole experimental period. ' $\mathrm{C} 198$ ' exhibited a relative longer RL (Fig. 2A) and more RN (Fig. 2B) only in 100- and 200-mm regimes. When subjected to a high dose of $\mathrm{NaCl}$ (i.e., $400 \mathrm{~mm}$ ), 'C198' had a shorter RL and fewer RN than the control level. ' $\mathrm{C} 43$ ' had a greater root growth than 'C198' regardless of salinity levels during the whole experimental period.

The salinity usually increased root fresh weight (RFW) of both genotypes when compared with the respective control level, except for $400 \mathrm{~mm}$-treated ' $\mathrm{C} 198$ ' that had a similar RFW to the control (Fig. 3A). There was no significant difference in
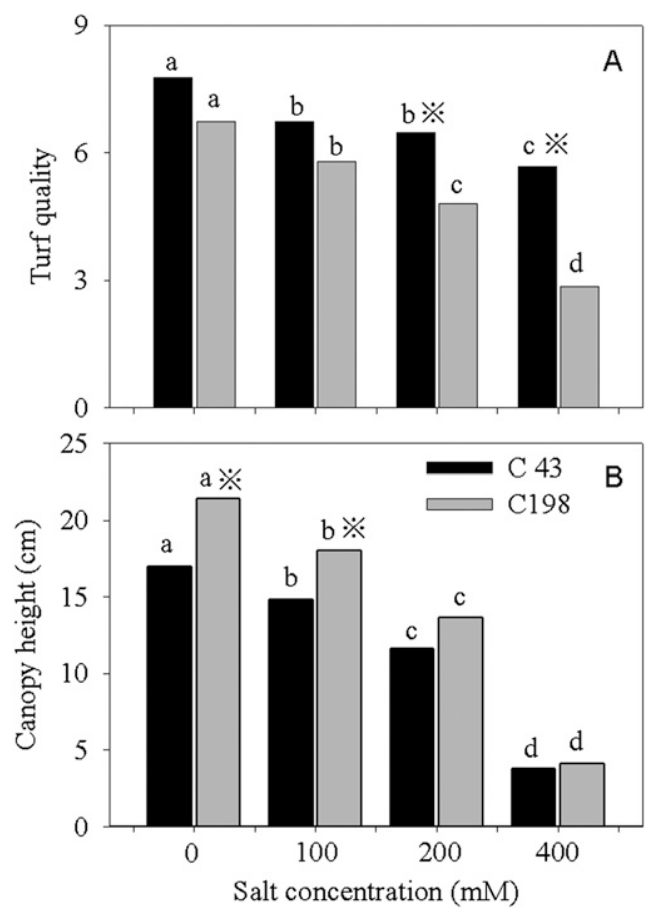

Fig. 1. Effects of salt stress on turf quality (A) and canopy height (B) in two bermudagrass genotypes ('C43' and 'C198') at $21 \mathrm{~d}$. Turf quality was visually assessed on a 1 to 9 scale. Letters marked by the same letters are not significant at $P<0.05$ (Tukey's test) for the comparison of salt concentration in a genotype; $※$ indicates significant difference at $P<0.05$ (Tukey's test) for the comparison of genotypes in a salt concentration $(n=6)$. 

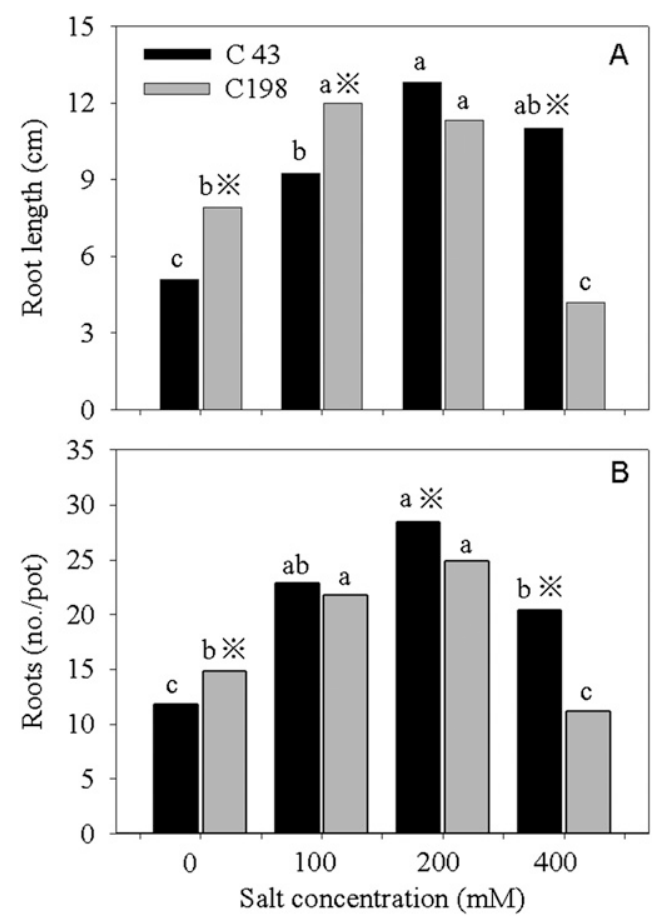

Fig. 2. Effects of salt stress on root length (A) and root number (B) in two bermudagrass genotypes ('C43' and 'C198') at $21 \mathrm{~d}$. Bars marked by the same letters are not significant at $P<0.05$ (Tukey's test) for the comparison of salt concentration in a genotype; $※$ indicates significant difference at $P<0.05$ (Tukey's test) for the comparison of genotypes in a salt concentration $(n=6)$.

RFW between two genotypes subjected to $100 \mathrm{~mm} \mathrm{NaCl}$. Root fresh weight, however, was greater in 'C43' vs. of 'C198' under moderate $(200 \mathrm{~mm})$ to high $(400 \mathrm{~mm})$ salt exposure.

The root/shoot length ratio was 0.3 to 0.47 under control level and similar between 'C43' and 'C198' (Fig. 3B). Salt stress increased root/shoot length ratio for both genotypes. When salinity increased from 0 to $400 \mathrm{~mm} \mathrm{NaCl}$, the ratio of root to shoot growth increased by twofold in ' $\mathrm{C} 198$ ' and ninefold in ' $\mathrm{C} 43$ '. The root/shoot length ratio was greater in ' $\mathrm{C} 43$ ' vs. ' $\mathrm{C} 198$ ' in 200- and 400-mm regimes.

IONIC RESPONSE TO SALT STRESS. The accumulation of $\mathrm{Na}^{+}$in shoots and roots of both bermudagrass genotypes significantly increased with increasing salinity level, but to a great extent in salt-sensitive 'C198' (Figs. 4A and 5A). $\mathrm{K}^{+}$content decreased with increasing salinity level in shoot and root of both genotypes (Figs. 4B and 5B). However, there was no difference for $\mathrm{K}^{+}$ content between two genotypes at each salt concentration.

The $\mathrm{Na}^{+} / \mathrm{K}^{+}$ratio was calculated from the $\mathrm{Na}^{+}$and $\mathrm{K}^{+}$ content. Salt treatment significantly increased the $\mathrm{Na}^{+} / \mathrm{K}^{+}$ratio in shoot and root of both genotypes, to a great extent in ' $\mathrm{C} 198$ ' than in 'C43' (Figs. 4C and 5C).

LiPID PEROXIDATION AND $\mathrm{H}_{2} \mathrm{O}_{2}$ LEVEL. No significant difference was observed in MDA content of new leaves for two bermudagrass genotypes subjected to 100 and $200 \mathrm{~mm} \mathrm{NaCl}$ when compared with the respective control (Fig. 6A). MDA content in new leaves of 'C198' had a 62\% higher level than those of ' $\mathrm{C} 43$ ' when exposed to $400 \mathrm{~mm} \mathrm{NaCl}$. Salt stress increased MDA content by 2.7 and 7.2 times in old leaves of 'C198' at moderate (200 mm) and high (400 mm) salt concentration, respectively, when compared with the control level (Fig. 6B). However, salt stress had no effects on MDA content in old leaves of ' $\mathrm{C} 43$ ' when compared with the control level.

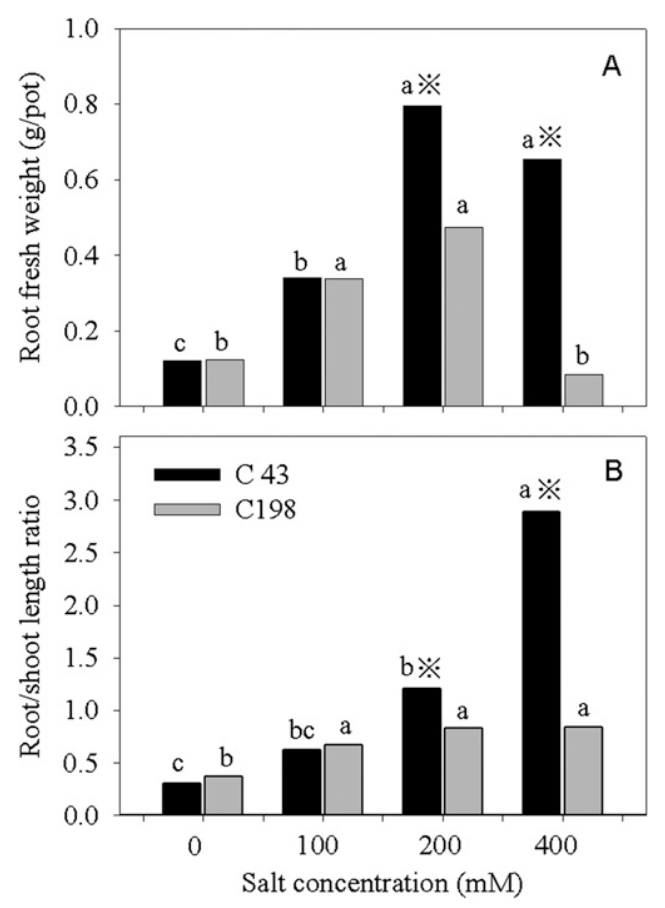

Fig. 3. Effects of salt stress on root fresh weight (A) and root/shoot length ratio (B) in two bermudagrass genotypes ('C43' and 'C198') at $21 \mathrm{~d}$. Bars marked by the same letters are not significant at $P<0.05$ (Tukey's test) for the comparison of salt concentration in a genotype; $※$ indicates significant difference at $P<0.05$ (Tukey's test) for the comparison of genotypes in a salt concentration $(\mathrm{n}=6)$.

There was no significant effect of salt on $\mathrm{H}_{2} \mathrm{O}_{2}$ level in new leaves of both genotypes, except at high ( $400 \mathrm{~mm})$ salt exposure (Fig. 6C). 'C43' had a higher $\mathrm{H}_{2} \mathrm{O}_{2}$ level in new leaves at mild $(100 \mathrm{~mm})$ salt exposure and control conditions. A significant increase in the accumulation of $\mathrm{H}_{2} \mathrm{O}_{2}$ was observed in the old leaves of 'C198' at moderate (200 mm) and high (400 mm) salt concentration when compared with control plants (Fig. 6D).

RESPONSES OF ANTIOXIDANT ENZYMES TO SALT STRESS. Moderate salt stress $(200 \mathrm{~mm})$ induced a greater level of SOD activity in new leaves of both genotypes when compared with the respective control level (Fig. 7A). No difference in SOD activity was observed for new leaves between two genotypes regardless of salinity levels (Fig. 7A). 'C43' old leaves had a greater level of SOD activity when subjected to the mild (100 $\mathrm{mm})$ and moderate $(200 \mathrm{~mm})$ salt stress and then declined to the control level at high (400 mm) salt exposure in old leaves (Fig. 7B). The SOD activity increased under $200 \mathrm{~mm} \mathrm{NaCl}$ stress, whereas it decreased under high (400 mM) salt exposure in old leaves of 'C198' when compared with the controls. 'C43' exhibited a greater level of SOD activity than C198 in old leaves under moderate and high salt exposure (Fig. 7B).

The CAT activity in new leaves increased under mild (100 $\mathrm{mm}$ ) salt stress for both genotypes, then declined to the control level for ' $\mathrm{C} 43$ ', and declined to a level lower than the control for 'C198' under moderate and high salt stress (Fig. 7C). ' $\mathrm{C} 198$ ' had a higher level of CAT activity than ' $\mathrm{C} 43$ ' in new leaves subjected to the control, mild, and moderate salt stress. The CAT activity in old leaves increased under mild salt stress but decreased under high salt stress in 'C198' when compared with the controls (Fig. 7D). Exposure to moderate $(200 \mathrm{~mm})$ salt stress resulted in an increase in CAT activity in 

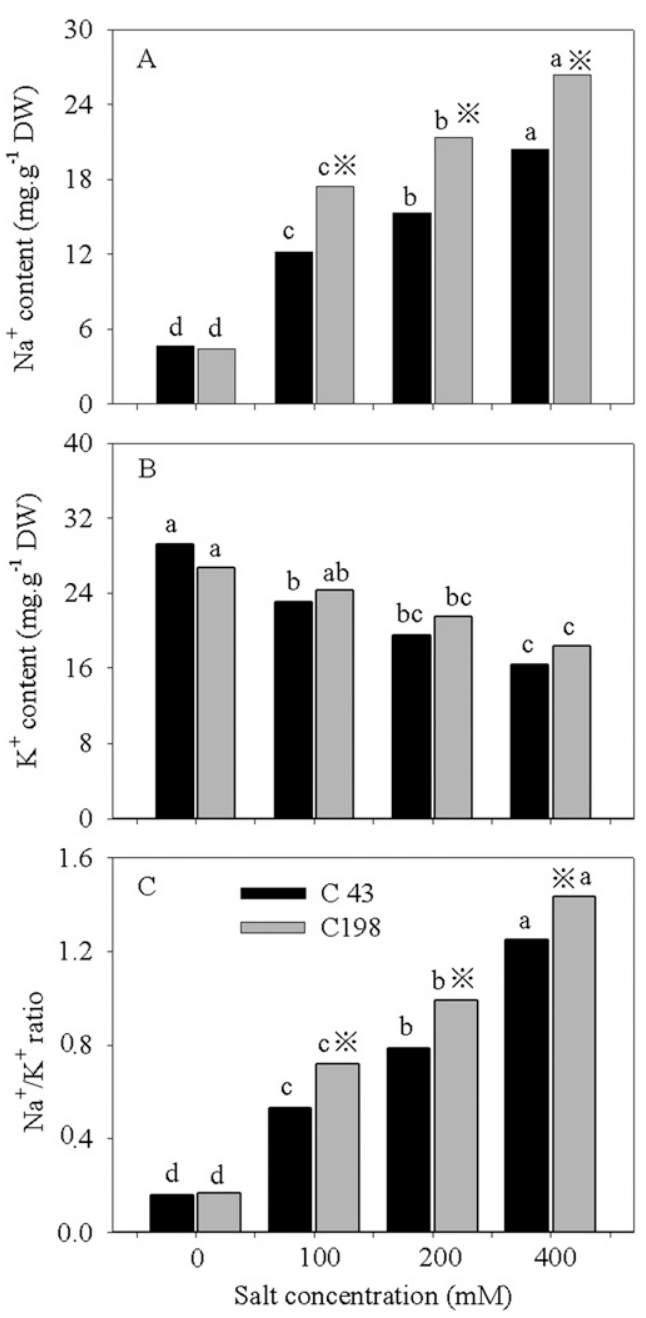

Fig. 4. Effects of salt stress on $\mathrm{Na}^{+}$content $(\mathbf{A}), \mathrm{K}^{+}$content $(\mathbf{B})$, and $\mathrm{Na}^{+} / \mathrm{K}^{+}$ratio (C) in shoots of two bermudagrass genotypes ('C43' and 'C198') at $21 \mathrm{~d}$. Bars marked by the same letters are not significant at $P<0.05$ (Tukey's test) for the comparison of salt concentration in a genotype; $※$ indicates significant difference at $P<0.05$ (Tukey's test) for the comparison of genotypes in a salt concentration $(\mathrm{n}=3)$.

old leaves of 'C43'. 'C43' had 38\% and 66\% higher CAT activity than ' $\mathrm{C} 198$ ' in old leaves under moderate or high doses of salt, respectively (Fig. 7D).

No difference in APX activity of new leaves was observed for two bermudagrass genotypes subjected to 100 and $200 \mathrm{~mm}$ $\mathrm{NaCl}$ when compared with the control (Fig. 8A). 'C198' new leaves had a $37 \%$ higher level of APX activity than ' $\mathrm{C} 43$ ' when exposed to $400 \mathrm{~mm} \mathrm{NaCl}$. Salt stress increased APX activity by $50 \%, 67 \%$, and $71 \%$ in old leaves of ' $\mathrm{C} 43$ ' at mild (100 mM), moderate $(200 \mathrm{~mm})$, and high $(400 \mathrm{~mm})$ salt concentrations, respectively, when compared with the control level (Fig. 8B). Mild (100 $\mathrm{mm})$ and moderate $(200 \mathrm{~mm})$ salt stress, however, had no effects on APX activity in old leaves of ' $\mathrm{C} 198$ '. A high level of salt concentration ( $400 \mathrm{~mm}$ ) caused an $88 \%$ decrease in APX activity when compared with the controls (Fig. 8B). APX activity in old leaves was higher in 'C43' vs. 'C198' when exposed to different salt concentrations.

Salt stress caused a $57 \%$ increase in DHAR activity at 100 $\mathrm{mm} \mathrm{NaCl}$ and a $35 \%$ decrease at $400 \mathrm{~mm}$ concentration in new leaves of ' $\mathrm{C} 43$ ' when compared with the controls (Fig. 8C). For
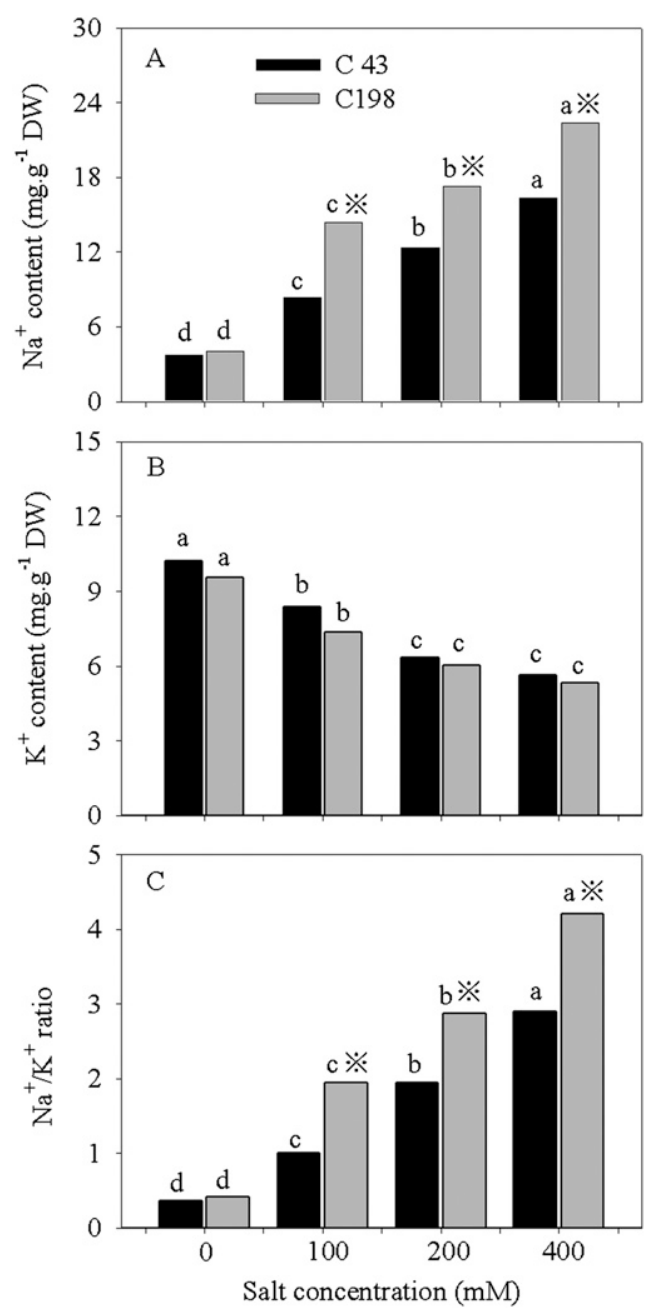

Fig. 5. Effects of salt stress on $\mathrm{Na}^{+}$content $(\mathbf{A}), \mathrm{K}^{+}$content $(\mathbf{B})$, and $\mathrm{Na}^{+} / \mathrm{K}^{+}$ratio (C) in roots of two bermudagrass genotypes ('C43' and 'C198') at $21 \mathrm{~d}$. Bars marked by the same letters are not significant at $P<0.05$ (Tukey's test) for the comparison of salt concentration in a genotype; $※$ indicates significant difference at $P<0.05$ (Tukey's test) for the comparison of genotypes in a salt concentration $(\mathrm{n}=3)$.

'C198', however, salinity induced a $47 \%$ and $72 \%$ increase at 200 and $400 \mathrm{~mm} \mathrm{NaCl}$, respectively. Salt stress had no effects on DHAR activity in old leaves of 'C43' (Fig. 6D). Mild (100 $\mathrm{mm})$ and moderate (200 $\mathrm{mm})$ salt concentration increased the DHAR activity in old leaves of 'C198' (Fig. 8D). 'C43' had a $37 \%$ higher level of DHAR activity than ' $\mathrm{C} 198$ ' in old leaves under control conditions and a $46 \%$ higher activity at high salt (400 mm) exposure. No difference in old leaves of DHAR activity was observed between two genotypes at mild (100 mM) and moderate (200 mM) salt exposure (Fig. 8D).

ANTIOXIDANT ENZYME GENE EXPRESSION. The abundance of $\mathrm{Cu} / \mathrm{Zn}$ SOD transcripts increased in new leaves and decreased in old leaves with increasing salinity levels in both genotypes when compared with the respective control (Fig. 9). No difference in $\mathrm{Cu} / \mathrm{Zn}$ SOD transcripts was observed in new leaves (Fig. 9A) between two genotypes. 'C43' old leaves had a greater expression level under moderate $(200 \mathrm{~mm})$ and high $(400 \mathrm{~mm})$ salt exposure (Fig. 9B).

The transcript level of $C A T$ was greater in new leaves but lower in old leaves under salt stress in two genotypes as 

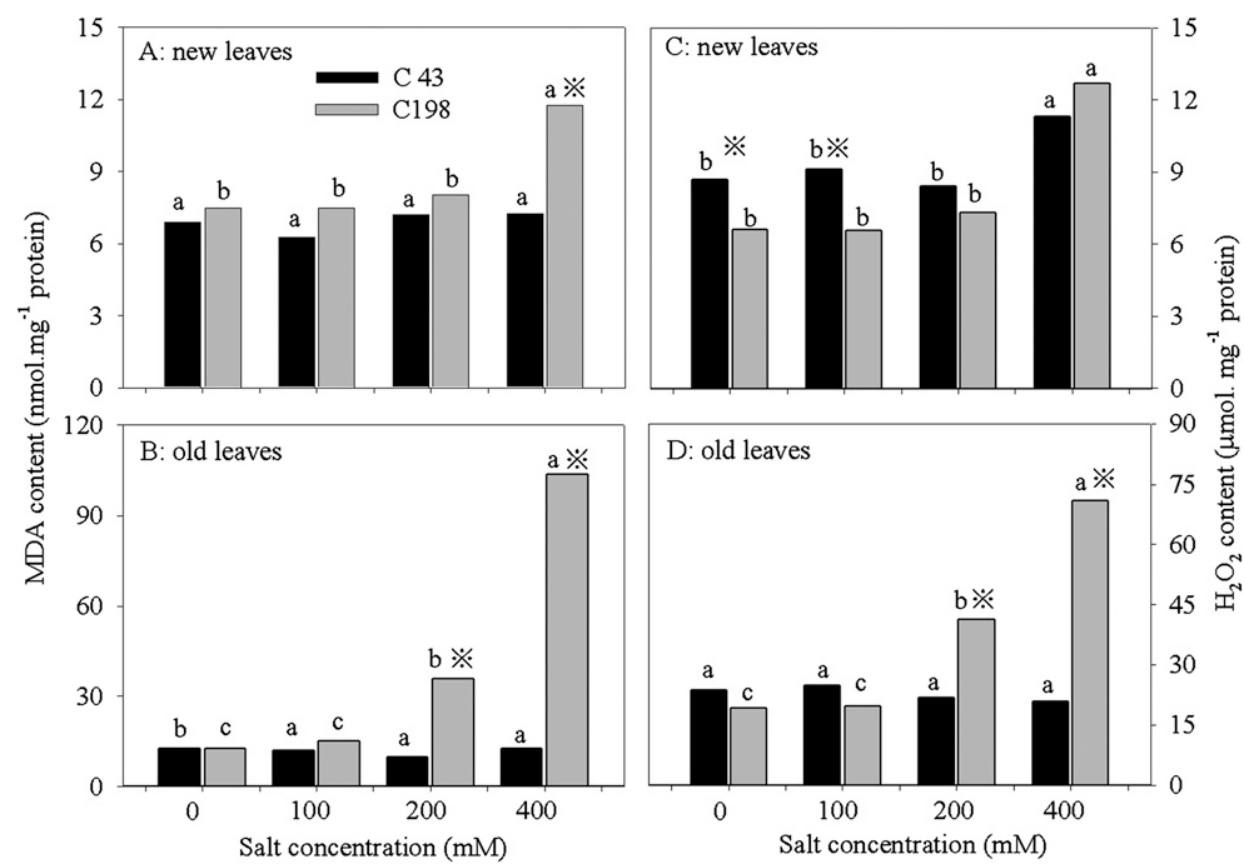

Fig. 6. Effects of salt stress on malondialdehyde (MDA) content [(A) new leaves, (B) old leaves] and $\mathrm{H}_{2} \mathrm{O}_{2}$ content [C) new leaves, (D) old leaves] in leaves of two bermudagrass genotypes ('C43' and 'C198') at $21 \mathrm{~d}$. Bars marked by the same letters are not significant at $P<0.05$ (Tukey's test) for the comparison of salt concentration in a genotype; $※$ indicates significant difference at $P<0.05$ (Tukey's test) for the comparison of genotypes in a salt concentration $(\mathrm{n}=3)$.
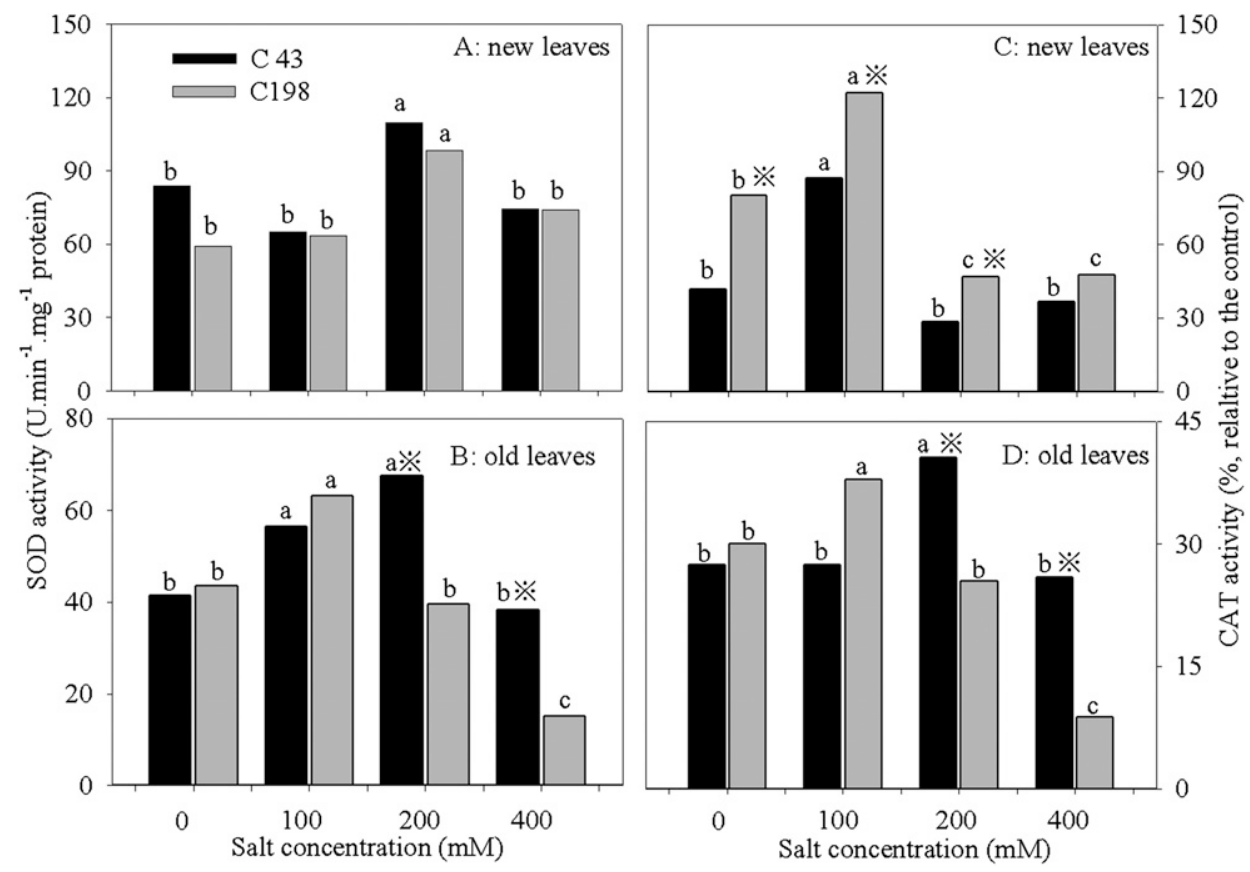

Fig. 7. Effects of salt stress on superoxide dismutase (SOD) activity [(A) new leaves, (B) old leaves] and catalase (CAT) activity [(C) new leaves, (D) old leaves] in leaves of two bermudagrass genotypes ('C43' and ' $\mathrm{C} 198$ ') at $21 \mathrm{~d}$. Bars marked by the same letters are not significant at $P<0.05$ (Tukey's test) for the comparison of salt concentration in a genotype; $\circledast$ indicates significant difference at $P<0.05$ (Tukey's test) for the comparison of genotypes in a salt concentration $(n=3)$.

compared with the control (Fig. 10). Salt-tolerant 'C43' exhibited a greater expression level in new leaves (Fig. 10A) and old leaves (Fig. 10B) under moderate (200 mM) and high (400 mM) salt treatment when compared with the ' $\mathrm{C} 198$ '.
$A P X$ transcripts increased in new leaves (Fig. 11A) of two saltstressed genotypes but unchanged in old leaves of C143. Salt-sensitive 'C198' had a lower level of APX transcript in the $400-\mathrm{mm} \mathrm{NaCl}$ regime (Fig. 11B). No differences in $A P X$ expressions of new leaves were observed between two genotypes. 'C143' old leaves exhibited a higher level of APX than 'C198' when exposed to $400 \mathrm{~mm} \mathrm{NaCl}$ (Fig. 11B).

The expressions of DHAR were induced in salt-stressed new leaves but suppressed in old leaves for both genotypes (Fig. 12). The $200 \mathrm{~mm}$ $\mathrm{NaCl}$-treated new leaves had the greatest expression of DHAR for two genotypes. However, the magnitude of changes varied in two genotypes under salt stress. Salttolerant ' $\mathrm{C} 43$ ' usually had a greater expression level of DHAR in 400 mM-treated new leaves (Fig. 12A) than 'C198'. Expression of DHAR was greater in old leaves of ' $\mathrm{C} 143$ ' vs. 'C198' exposed to 200 and 400 mм $\mathrm{NaCl}$ (Fig. 12B).

\section{Discussion}

Growth RESPONSE TO SALt STRESS. Salt stress showed a remarkable effect on the shoot and root growth of bermudagrass genotypes differing in salt tolerance. The reduction in canopy height under salt stress was associated with the increasing $\mathrm{Na}^{+}, \mathrm{Na}^{+} / \mathrm{K}^{+}$ratio, and reduction of $\mathrm{K}^{+}$. These results suggested that growth inhibition could be related to the osmotic and ionic effects (nutritional deficiency and/or imbalance). Growth parameters such as shoot growth, root growth, and TQ have been reported to be excellent criteria to determine salinity tolerance in turfgrasses (Marcum, 1999; Marcum and Kopec, 1997). In our study, 'C43' maintained a relatively higher TQ and root growth under salinity conditions, indicating that the tolerance of ' $\mathrm{C} 43$ ' could be related to the development and maintenance of a more extensive root system under saline conditions.

Several investigators have demonstrated that shoot growth is more sensitive to salinity than root growth and leads to an increased root/shoot ratio (Bernstain et al., 2001; Qian et al., 2000). Our results also showed that the shoot of bermudagrass is more sensitive to salinity than the root system. 

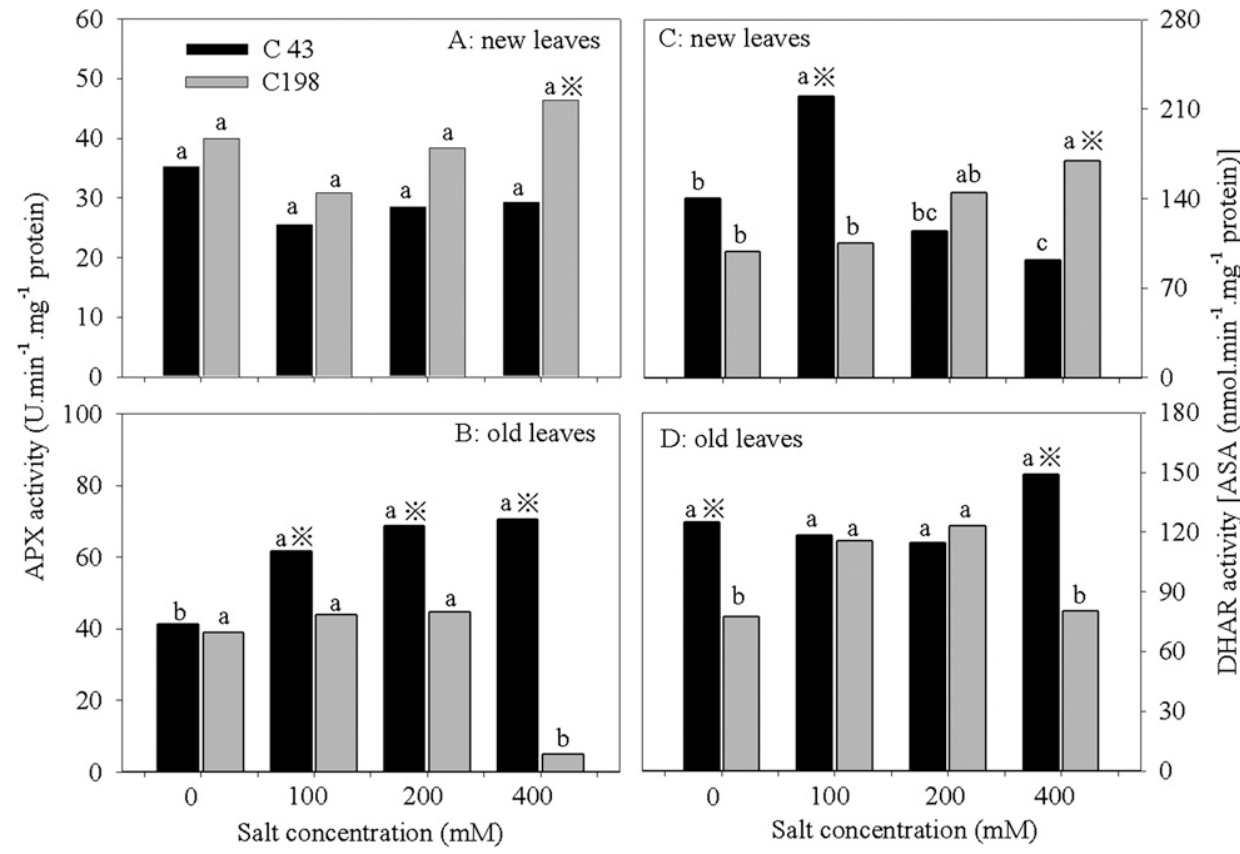

Fig. 8. Effects of salt stress on ascorbate peroxidase (APX) activity [(A) new leaves, (B) old leaves] and dehydroascorbate reductase (DHAR) activity [(C) new leaves, (D) old leaves; ASA = ascorbic acid] in leaves of two bermudagrass genotypes ('C43' and ' $\mathrm{C} 198$ ') at $21 \mathrm{~d}$. Bars marked by the same letters are not significant at $P<0.05$ (Tukey's test) for the comparison of salt concentration in a genotype; $¥$ indicates significant difference at $P<0.05$ (Tukey's test) for the comparison of genotypes in a salt concentration $(\mathrm{n}=3)$.
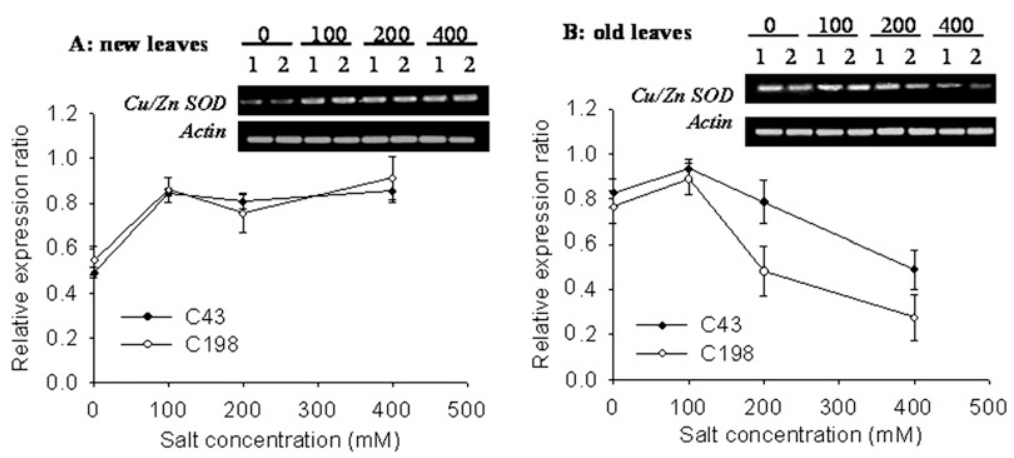

Fig. 9. Effects of salt stress on copper/zinc superoxide dismutase (Cu/Zn SOD) gene expression in leaves [(A) new leaves, (B) old leaves] of two bermudagrass genotypes (1, 'C43'; 2, 'C198') at $21 \mathrm{~d}$. The transcript levels were quantified by densitometry and gene expression levels was calculated relative to the amount of Actin gene. The quantifications are given in the graph. Vertical bars represent SD of the mean values $(\mathrm{n}=3)$.

Compared with the shoot growth, the root growth of the two bermudagrass genotypes was less affected or even stimulated by salt stress, particularly in salt-tolerant ' $\mathrm{C} 43$ '. This was in agreement with the previous reports on warm-season or more stresstolerant grasses/halophytes (Marcum et al., 2005; Pessarakli and Kopec, 2004; Pessarakli et al., 2005; Sagi et al., 1997).

Higher resource allocation to root growth is a symptom of water stress and/or nonoptimal nutritional conditions in the root environment (Bell and O'Leary, 2003). In our study, the root/ shoot length ratio was higher than the control level in two bermudagrass genotypes under salinity conditions, particularly in salt-tolerant ' $\mathrm{C} 43$ ', indicating greater allocation of metabolites and energy for root growth relative to shoot growth. Saltstressed roots emphasize elongation growth, which helps them explore the soil to seek a more optimal environment from which to acquire water and minerals (McCarty and Dudeck, 1993). Bermudagrass allocates more resources to root growth relative to shoot growth under salt stress. It seems that the need to find deeper freshwater and nutrient in a saline habitat exceeds the need to increase the shoot growth for light and photosynthetic carbon gain. The proposed explanations for the root growth stimulation were attributed to the maintenance of a high photosynthetic rate despite retardation of shoot growth, reduced percentage defoliation resulting from shoot growth retardation, or a differential response of shoots and roots to phytohormones (Youngner and Lunt, 1967).

Physiological Response to SALT STRESS. The MDA content is generally used as an indicator of oxidative damages induced by salinity stress (Hernández and Almansa, 2002). Our results showed that a remarkable increase in leaf MDA content in salt-sensitive 'C198' under high (400 mM) salt stress indicated a higher rate of lipid peroxidation for ' $\mathrm{C} 198$ ' as a result of salt stress and salt-tolerant ' $\mathrm{C} 43$ ' might have better protection against oxidative damage. The lower oxidative damages in leaves of ' $\mathrm{C} 43$ ' as compared with 'C198' may reflect a more efficient antioxidative system as evidenced by a higher activity of SOD, CAT, APX, and DHAR enzymes.

The increased, decreased, and unchanged antioxidant enzyme activities in the new and old leaves of bermudagrass indicate a different antioxidant metabolism in response to salt stress. SOD plays a key role for maintaining normal physiological processes and coping with oxidative stress by rapidly converting $\mathrm{O}_{2}{ }^{-}$to $\mathrm{O}_{2}$ and $\mathrm{H}_{2} \mathrm{O}_{2}$ (Mittler, 2002). The effects of salt stress on SOD activity varied at interspecific and intraspecific levels and the age of tissue or organ (Ashraf, 2009). In our study, the activity of SOD was increased more in the old leaves of the tolerant genotype ('C43') and slightly increased or even decreased in SOD activity in the sensitive genotype ('C198'). Such a differential response to salt stress has been reported between cultivars of potato [Solanum tuberosum (Rahnama and Ebrahimzadeh, 2005)], millet [Setaria italica (Sreenivasulu et al., 2000)], wheat [Triticum aestivum (Sairam et al., 2002)], and strawberry [Fragaria vesca (Turhan and Gulen Erics, 2008)]. These results suggested that the SOD activities can be induced by ROS under salt stress and the salt-tolerant genotype has a better $\mathrm{O}_{2}{ }^{\bullet}$ radical scavenging ability. Although the SOD activity in new leaves was unaffected or only increased at $200 \mathrm{~mm} \mathrm{NaCl}$, the total activity exhibit a greater level than in old leaves (Fig. 5). 

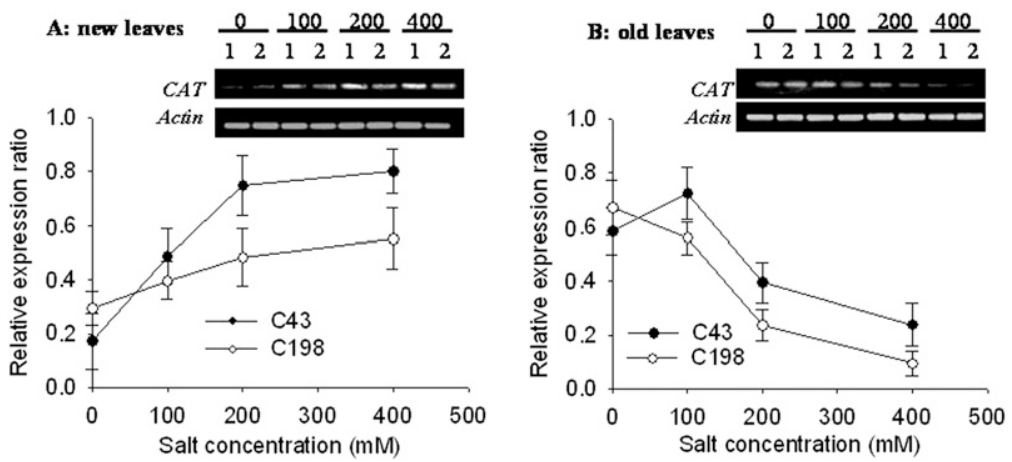

Fig. 10. Effects of salt stress on catalase (CAT) gene expression in leaves [(A) new leaves, $(\mathbf{B})$ old leaves] of two bermudagrass genotypes (1, 'C43'; 2, 'C198') at $21 \mathrm{~d}$. The transcript levels were quantified by densitometry, and gene expression levels were calculated relative to the amount of Actin gene. The quantifications are given in the graph. Vertical bars represent SD of the mean values $(\mathrm{n}=3)$.
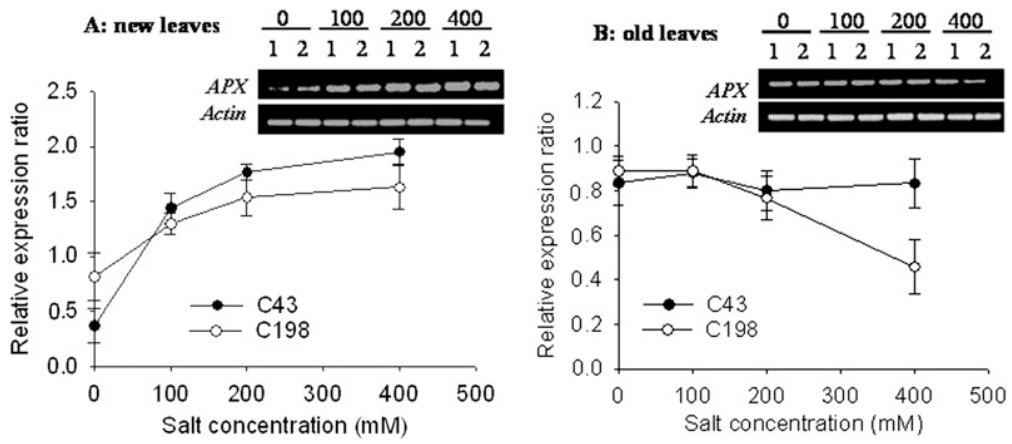

Fig. 11. Effects of salt on ascorbate peroxidase (APX) gene expression in leaves [(A) new leaves, (B) old leaves] of two bermudagrass genotypes ( 1, ' $\mathrm{C} 43$ '; 2 , 'C198') at $21 \mathrm{~d}$. The transcript levels were quantified by densitometry, and gene expression levels were calculated relative to the amount of Actin gene. The quantifications are given in the graph. Vertical bars represent SD of the mean values $(\mathrm{n}=3)$.
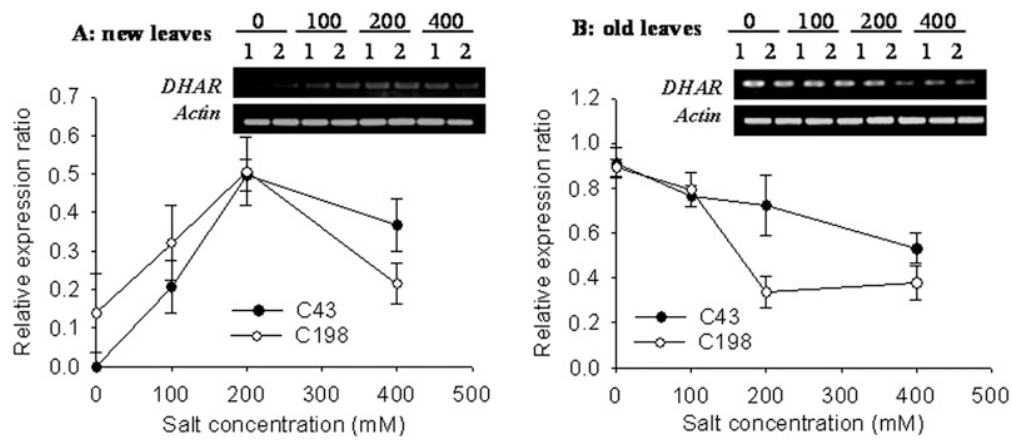

Fig. 12. Effects of salt on dehydro-ascorbate reductase (DHAR) gene expression in leaves [(A) new leaves, (B) old leaves] of two bermudagrass genotypes (1, 'C43'; 2, 'C198') at $21 \mathrm{~d}$. The transcript levels were quantified by densitometry, and gene expression levels were calculated relative to the amount of Actin gene. The quantifications are given in the graph. Vertical bars represent SD of the mean values $(\mathrm{n}=3)$.

These results suggested that higher antioxidant defense existed in new leaves than in old leaves leading to new leaf survival and maintaining growth under salinity conditions.

Catalase is one of the important enzymes that scavenge $\mathrm{H}_{2} \mathrm{O}_{2}$, the product of SOD-facilitated reactions, by directly breaking it down to $\mathrm{H}_{2} \mathrm{O}$ and $\mathrm{O}_{2}$ (Mittler, 2002). The CAT activity increased in salt-stressed tobacco [Nicotiana tabacum
(Savoure et al., 1999)], tomato [Lycopersicon pennellii (Rodriguez-Rosales et al., 1999)], and mulberry [Morus alba (Sudhakar et al., 2001)]. However, unchanged CAT activity under salt stress was also observed in potato (Benavides et al., 2000) and rice [Oryza sativa (Lin and Kao, 2000)]. Khosravinejad et al. (2008) and Seckin et al. (2010) observed a rapid and continued increase in CAT activity of salt-tolerant barley (Hordeum vulgare) cultivars under salt stress. In the present study, CAT activity increased under mild to moderate stress but declined at a high salt concentration for salt-sensitive ' $\mathrm{C} 198$ ' when compared with the control plants. These results indicated that the changes in CAT activity may depend on the plant species, the development and metabolic state of the plant as well as on the duration and intensity of the stress (Chaparzadeh et al., 2004). The level of $\mathrm{H}_{2} \mathrm{O}_{2}$ in new leaves was lower in 'C198' than 'C43' under control and mild salt exposure with a higher CAT activity in ' $\mathrm{C} 198$ ' than that of ' $\mathrm{C} 43$ ' and vs. in old leaves under moderate and high salt treatment. These results suggested that CAT may play a major role in scavenging $\mathrm{H}_{2} \mathrm{O}_{2}$ for bermudagrass under salt stress.

In addition to CAT, an alternative and more effective detoxification mechanism against $\mathrm{H}_{2} \mathrm{O}_{2}$ was the ascorbate-glutathione cycle (GSH-ASC) (Asada and Takahashi, 1987). The cycle maintains a ratio of reduced peroxidized ASA and GSH for proper scavenging ROS in plant cells (Mittler, 2002). APX and DHAR are major ascorbate-reducing enzymes in the GSH-ASC cycle that scavenges $\mathrm{H}_{2} \mathrm{O}_{2}$ (Parvaiz and Satyawati, 2008). Our results showed that APX activities increased in old leaves and did not change in new leaves of salt-tolerant genotype under salinity conditions. The enhancement of APX activities suggested that salt-triggered antioxidative capacity might be responsible for the removal of excessive $\mathrm{H}_{2} \mathrm{O}_{2}$ in old leaves. However, the DHAR activity in old or new leaves showed variations for two genotypes exposed to different salinity levels. These results indicated that the different responses of these enzyme activities to salt stress may depend on plant species, stress severity, and intensity of ROS production in different tissues (Bian and Jiang, 2009). Generally, the increased or unchanged APX and DHAR activities in the leaves of bermudagrass under salt stress may help maintain proper levels of ASA and GSH, the two important antioxidants against ROS toxicity (Foyer et al., 1994).

The comparison of the genotype-dependent response pattern for SOD, CAT, APX, and DHAR activities to salt stress indicated significant genotypic difference at different concentrations of salt exposure. The SOD, CAT, and APX seem to be 
the key enzymes in determining salt tolerance in bermudagrass, because their activities were much higher in salt-tolerant leaves than the sensitive ones under medium to high salt stress. The decreased activities of SOD, CAT, and APX in old leaves of salt-sensitive genotype at high salt stress $(400 \mathrm{~mm} \mathrm{NaCl})$ were probably the result of the harmful effect of overproduction of ROS or its poisonous ROS derivatives in old leaves over the new leaves or the tolerant genotype ' $\mathrm{C} 43$ '. The expression patterns of SOD, CAT, APX, and DHAR in old and new leaves were not totally consistent with the enzyme activities in both genotypes. These suggested that the abundance of a particular transcript does not always correlate with corresponding changes in antioxidant protein levels and/or enzyme activities (Mullineaux and Creissen, 1997).

In conclusion, salt stress $(100,200$, and $400 \mathrm{~mm} \mathrm{NaCl})$ significantly inhibited shoot growth in both genotypes and stimulated root growth (except $400 \mathrm{~mm}$ for 'C198'). Differences in growth response and salinity tolerance between the two genotypes was attributed largely to the development and maintenance of a more extensive root system under saline conditions and induced antioxidant gene expressions, leading to more efficient enzyme stimulation and protection in bermudagrass. These criteria might effectively be used in breeding programs to select and develop salt-tolerant bermudagrass cultivars.

\section{Literature Cited}

Abdul-Jaleel, C., R. Gopi, G.M.A. Lakshmanan, and R. Panneerselvam. 2006. Triadimefon induced changes in the antioxidant metabolism and ajmalicine production in Catharanthus roseus (L.) G. Don. Plant Sci. 171:271-276.

Adavi, Z., K. Razmjoo, and M. Mobli. 2006. Salinity tolerance of bermudagrass (Cynodon spp. L.C. Rich) cultivars and shoot Na, K and $\mathrm{Cl}$ contents under a high saline environment. J. Hort. Sci. Biotechnol. 81:1074-1078.

Akram, N.A., M. Shahbaz, H.R. Athar, and M. Ashraf. 2006. Morphophysiological responses of two differently adapted populations of Cynodon dactylon (L.) Pers. and Cenchrus ciliaris L. to salt stress. Pak. J. Bot. 38:1581-1588.

Alshammary, S.F., G. Hussain, and Y.L. Qian. 2008. Response of four warm-season grasses to saline irrigation water under arid climate. Asian J. Plant Sci. 7:619-627.

Amor, N.B., A. Jiménez, W. Megdiche, M. Lundqvist, F. Sevilla, and C. Abdelly. 2006. Response of antioxidant systems to $\mathrm{NaCl}$ stress in the halophyte Cakile maritima. Physiol. Plant. 126:446-457.

Asada, K. and M. Takahashi. 1987. Production and scavenging of active oxygen in photosynthesis, p. 227-287. In: Kyle, D.J., C.B. Osmond, and C.J. Arntzen (eds.). Photoinhibition. Elsevier, Amsterdam, The Netherlands.

Ashraf, M. 2009. Biotechnological approach of improving plant salt tolerance using antioxidants as markers. Biotechnol. Adv. 27:84-93.

Bell, H.L. and J.W. O'Leary. 2003. Effects of salinity on growth and cation accumulation of Sporobolus virginicus (Poaceae). Amer. J. Bot. 90:1416-1424.

Benavides, P.M., L.P. Marconi, M.S. Gallego, E.M. Comba, and L.M. Tomaro. 2000. Relationship between antioxidant defence systems and salt-tolerance in Solanum tuberosum. Aust. J. Plant Physiol. 27:273-278.

Bernstain, N., M. Ioffe, and M. Zilberstaine. 2001. Salt-stress effects on avocado rootstock growth. I. Establishing criteria for determination of shoot growth sensitivity on the stress. Plant Soil 233:1-11.

Bian, S. and Y. Jiang. 2009. Reactive oxygen species, antioxidant enzyme activities and gene expression patterns in leaves and roots of kentucky bluegrass in response to drought stress and recovery. Sci. Hort. 120:264-270.
Bradford, M.M. 1976. A rapid and sensitive method for quantitation of microgram quantities of protein utilizing the principle of protein dye-binding. Anal. Biochem. 72:248-254.

Chaparzadeh, N., M.L. Amico, R.K. Nejad, R. Izzo, and F.N. Izzo. 2004. Antioxidative responses of Calendula officinalis under salinity conditions. Plant Physiol. Biochem. 42:695-701.

Edreva, A. 2005. Generation and scavenging of reactive oxygen species in chloroplasts: A submolecular approach. Agr. Ecosyst. Environ. 106:119-33.

Foyer, C.H., M. Lelandais, and K.J. Kunert. 1994. Photooxidative stress in plant. Physiol. Plant. 92:696-717.

Hameed, M., M. Ashraf, N. Naz, and F. Al-Qurainy. 2010. Anatomical adaptations of Cynodon dactylon L pers., from the salt range Pakistan, to salinity stress. I. Root and stem anatomy. Pak. J. Bot. 42:279-289.

Hare, P.D., W.A. Cress, and J. van Staden. 1997. The involvement of cytokinins in plant responses to environmental stress. Plant Growth Regulat. 23:79-103.

Heath, R.L. and L. Packer. 1968. Photoperoxidation in isolated chloroplasts. I. Kinetics and stoichiometry of fatty acid peroxidation. Arch. Biochem. Biophys. 125:189-198.

Hernández, J.A. and M.S. Almansa. 2002. Short-term effects of salt stress on antioxidant systems and leaf water relations of pea leaves. Physiol. Plant. 115:251-257.

Hoagland, D.R. and D.I. Arnon. 1950. The water-culture method for growing plants without soil. California Agr. Expt. Sta. Circ. 347.

Hu, L., H. Li, H. Pang, and J. Fu. 2012a. Responses of antioxidant gene, protein and enzymes to salinity stress in two genotypes of perennial ryegrass (Lolium perenne) differing in salt tolerance. J. Plant Physiol. 169:146-156.

Hu, L., T. Hu, X. Zhang, H. Pang, and J. Fu. 2012b. Exogenous glycine betaine ameliorates the adverse effect of salt stress on perennial ryegrass (Lolium perenne L.). J. Amer. Soc. Hort. Sci. 137: $38-46$.

Huang, B. and L. Liu. 2009. Physiological responses of creeping bentgrass to heat stress affected by phosphonate fungicide application. Intl. Turfgrass Soc. Res. J. 11:799-806.

Hulusi, K., B. Melike, Ö. Filiz, and T. İsmail. 2007. The effect of salt stress on lipid peroxidation, antioxidative enzymes and proline content of sesame cultivars. Environ. Exp. Bot. 60:344-351.

Jena, S. and M.A. Choudhuri. 1981. Glycolate metabolism of three submerged aquatic angiosperms during aging. Aquat. Bot. 12:345354.

Khosravinejad, F., R. Heydari, and T. Farboodnia. 2008. Antioxidant responses of two barley varieties to saline stress. Res. J. Biol. Sci. 3:486-490.

Lin, C. and C. Kao. 2000. Effect of $\mathrm{NaCl}$ stress on $\mathrm{H}_{2} \mathrm{O}_{2}$ metabolism in rice leaves. Plant Growth Regulat. 30:151-155.

Lu, S., X. Peng, Z. Guo, G. Zhang, Z. Wang, C. Wang, C. Pang, Z. Fan, and J. Wang. 2007. In vitro selection of salinity tolerant variants from triploid bermudagrass (Cynodon transvaalensis $\times C$. dactylon) and their physiological responses to salt and drought stress. Plant Cell Rpt. 26:1413-1420.

Mancino, C. and I.L. Pepper. 1994. Effects of wastewater on the turfgrass/soil environment, p. 121-135. In: Snow, J.T., M.P. Kenna, K.S. Erusha, M. Henry, C.H. Peacock, and J.R. Watson (eds.). Waste water reuse for golf course irrigation. Lewis Publisher, Chelsea, MI.

Marcum, K.B. 1999. Salinity tolerance mechanisms of grasses in the subfamily Chloridodeae. Crop Sci. 39:1153-1160.

Marcum, K.B. and D.M. Kopec. 1997. Salinity tolerance of turfgrasses and alternative species in the subfamily chloridodeae (Poaceae). Intl. Turfgrass Soc. Res. J. 8:735-742.

Marcum, K.B. and M. Pessarakli. 2006. Salinity tolerance and salt gland excretion efficiency of bermudagrass turf cultivars. Crop Sci. 46:2571-2574. 
Marcum, K.B., M. Pessarakli, and D.M. Kopec. 2005. Relative salinity tolerance of 21 turf-type desert saltgrasses compared to bermudagrass. HortScience 40:827-829.

McCarty, L.B. and A.E. Dudeck. 1993. Salinity effects on bentgrass germination. HortScience 28:15-17.

Mhadhbi, H., V. Fotopoulos, P.V. Mylona, M. Jebara, M. Elarbi Aouani, and A.N. Polidoros. 2011. Antioxidant gene-enzyme responses in Medicago truncatula genotypes with different degree of sensitivity to salinity. Physiol. Plant. 141:201-214.

Mittler, R. 2002. Oxidative stress, antioxidants and stress tolerance. Trends Plant Sci. 7:405-410.

Mittova, V., M. Tal, M. Volokita, and M. Guy. 2003. Up-regulation of the leaf mitochondrial and peroxisomal antioxidative systems in response to salt-induced oxidative stress in the wild salt-tolerant tomato species Lycopersicon pennellii. Plant Cell Environ. 26:845856.

Mullineaux, P.M. and G.P. Creissen. 1997. Glutathione reductase: Regulation and role in oxidative stress, p. 667-714. In: Scandalios, J. (ed.). Oxidative stress and the molecular biology of antioxidant defenses. Cold Spring Harbor Laboratory Press, New York, NY.

Munns, R. 2002. Comparative physiology of salt and water stress. Plant Cell Environ. 25:239-250.

Munns, R. and M. Tester. 2008. Mechanism of salinity tolerance. Annu. Rev. Plant Biol. 59:651-681.

Murillo-Amador, B., H.G. Jones, C. Kaya, R.L. Guilar, J.L. GarciaHernandez, E. Troyo-Dieguez, N.Y. Avila-Serrano, and E. RuedaPuente. 2006. Effects of foliar application of calcium nitrate on growth and physiological attributes of cowpea (Vigna unguiculata L.) grown under salt stress. Environ. Exp. Bot. 58:188-196.

Nakano, Y. and K. Asada. 1981. Hydrogen peroxide is scavenged by ascorbate specific peroxidase in spinach chloroplasts. Plant Cell Physiol. 22:867-880.

Parvaiz, A. and S. Satyawati. 2008. Salt stress and phyto-biochemical responses of plants - A review. Plant Soil Environ. 54:89-99.

Pessarakli, M. and D.M. Kopec. 2004. Growth responses of bermudagrass and Seashore Paspalum to different levels of FerroGrow multinutrient fertilizer. J. Food Agr. Environ. 2:284-286.

Pessarakli, M., K.B. Marcum, and D.M. Kopec. 2005. Growth responses and nitrogen-15 absorption of desert saltgrass (Distichlis spicata L.) to salinity stress. J. Plant Nutr. 28:1441-1452.

Qian, Y.L., M.C. Engelke, and M.J.V. Foster. 2000. Salinity effects on zoysiagrass cultivars and experimental lines. Crop Sci. 40:488-492.

Rahnama, H. and H. Ebrahimzadeh. 2005. The effect of $\mathrm{NaCl}$ on antioxidant enzyme activities in potato seedlings. Biol. Plant. 49: 93-97.
Rodriguez-Rosales, M.P., L. Kerkeb, P. Bueno, and J.P. Donaire. 1999. Changes induced by $\mathrm{NaCl}$ in lipid content and composition, lipoxygenase, plasma membrane $\mathrm{H}^{+}$-ATPase and antioxidant enzyme activities of tomato (Lycopersicon esculentum Mill.) calli. Plant Sci. 143:143-150.

Sagi, M., N.A. Savidov, N.P. L'vov, and S.H. Lips. 1997. Nitrate reductase and molybdenum cofactor in annual ryegrass as affected by salinity and nitrogen source. Physiol. Plant. 99:546-553.

Sairam, R.K., K.V. Rao, and G.C. Srivastava. 2002. Differential response of wheat genotypes to long term salinity stress in relation to oxidative stress, antioxidant activity and osmolyte concentration. Plant Sci. 163:1037-1046.

Savoure, A., D. Thorin, M. Davey, X.J. Hua, S. Mauro, M. Van Montagu, D. Inze, and N. Verbruggen. 1999. $\mathrm{NaCl}$ and $\mathrm{CuSO}_{4}$ treatments trigger distinct oxidative defense mechanisms in Nicotiana plumbaginifolia L. Plant Cell Environ. 22:387-396.

Seckin, B., I. Turkan, A.H. Sekmen, and C. Ozfidan. 2010. The role of antioxidant defense systems at differential salt tolerance of Hordeum marinum Huds. (sea barleygrass) and Hordeum vulgare L. (cultivated barley). Environ. Exp. Bot. 69:76-85.

Sen Gupta, A.S., J.L. Heinen, A.S. Holaday, J.J. Burke, and R.D. Allen. 1993. Increased resistance to oxidative stress in transgenic plants that overexpress chloroplastic $\mathrm{Cu} / \mathrm{Zn}$ superoxide dismutase. Proc. Natl. Acad. Sci. USA 90:1629-1633.

Shahba, M.A. 2010. Interaction effects of salinity and mowing on performance and physiology of bermudagrass cultivars. Crop Sci. 50:2620-2631.

Sigaud-Kutner, T.C.S., E. Pinto, O.K. Okamoto, L.R. Latorre, and P. Colepicolo. 2002. Changes in superoxide dismutase activity and photosynthetic pigment content during growth of marine phytoplankters in batch-cultures. Physiol. Plant. 114:566-571.

Sreenivasulu, N., B. Grimm, U. Wobus, and W. Weschke. 2000. Differential response of antioxidant compounds to salinity stress in salt tolerant and salt sensitive seedlings of foxtail millet (Setaria italica). Physiol. Plant. 109:435-442.

Sudhakar, C., A. Lakshmi, and S. Giridarakumar. 2001. Changes in the antioxidant enzyme efficacy in two high yielding genotypes of mulberry (Morus alba L.) under $\mathrm{NaCl}$ salinity. Plant Sci. 161:613619.

Turhan, E. and A. Gulen Erics. 2008. The activity of antioxidative enzymes in three strawberry cultivars related to salt-stress tolerance. Acta Physiol. Plant. 30:201-208.

Youngner, V.B. and O.R. Lunt. 1967. Salinity effects on roots and tops of bermudagrass. Grass Forage Sci. 22:257-259.

Zhu, J.K. 2001. Plant salt tolerance. Trends Plant Sci. 6:66-71. 